Territory of Alaska Depertiment of Mnes

\section{PROPERTY OF LIBRARY \\ STATE OF ALASKA DIVISION OF GEOLOGICAL SURVEY}

T D M BULCETIN

June 1956
P. O. Box 1391

Juneau, Aleska

VOL. IV

No.

\title{
MTNING ACTIVITIES
}

FIRST DIVISION - Unton Carbide Nuclear, having signed a contract for the I \& L uranium property some time ago, is now endeavoring to clear the title to the claims. If successful, they plan a drilling program there. The I \& I adjolns the original Ross-Adams discovery on southern Prince of Wales Island. A tractor roed is planned from the beach to the propertles, and at last report, Climax Molybdenum Co. was planging to ship from the Ross-Adams property this sumer.

Columbia Iron Mining Co., a subsidiary of U.S. Steel w11l be active in the Ketchikan area again this year. In addition to other activities, they are staking limestone claims.

Klukwan Iron Ore Co. has started further development work on their Iron deposit near Haines. Newspaper releases indicate an interest in this deposit by U. S. Steel.

FOURIA DIVIBION - Mercury production at the Red Devil Mine on the Kuskokndm appears to have levelled off to an average of about 1250 pounds per day from the reported 2000 pounds at the start three months ago.

\section{OIL NEWS}

Drilling has been resumed at Houston, 30 miles north of Anchorage. Crews are working on a 24-hour basis and are reportedly pest the 2,600-foot mark on what Is expected to be a 10,000-foot well. The Anchorage Gas and 011 Development controls an 86,000 -acre block of leases in the Houston area.

\section{TITLE TROUBLES}

TMM has many times urged prospectors to do everything possible to keep the titles to their claims in the clear. In addition to the anmual assesament work and recording of proper affidavits, this includes making certaln that all agreenents entered into with other perties conceraing the claims are clear, understandable, and in proper legel form. One of the first things an examining engineer or company looks into is status of title. Without clear title, nothing will proceed. A case in point Is mentioned in the Plrst paragraph of this bulletin. Once the option on a prospect has been dropped due to title afflculties, other prospective investors are reluctant to make any kind of a deal.

\section{ARIZONA MINERS PROTEST}

A news story from the Phoenix Gazette entitled "New Mining Law Applled In Btate" has disturbed the mine operators of Arizona. The law referred to is Public L8w 167 which epplies to Alaske as well as Arlzone. In the article, the reglonal forester at Albuquerque was quoted as seylng that examination of thousands of old minfing claims 18 underway and "urged claim owmers to place thelr holdings under voluntary provisions of the law to save themselves time and the government and taxpayers the costs of long-drawn-out expminetions and hearings in Artzone and New Moxico." 
Under P I 167, on whtch we reported in our October 1955 18sue, claims located after July 23, 1955; and prior to patent, shall not be uBed for any purpose otber then those incident to prospecting or mining. Also, the U.S. is given the right to manage and sell the surface resolurces Including the timber (prior to petent) so long as it does not interfere with the prospecting or mining operations of the claim bolder. The article referred to implied that the Forest Service intended to leunch a wolesale investigation of mining clatms on forest lands, and that those with clafms located prior to P I 167 had better be prepared to spend the time and money necessary to Justify their locations.

The Secretary of the Arlaona Small Mine Operators Assoclation asked the Forest Service for a statement of clariflcation, writing as follows: "We hold no brlef for those who located and have been holding minlng claims for other than miniag purposes and we feel as you do that these claims should be Invalidated. Eowever, it is a subject which should be approeched carefuliy and caut1ourly if good falth 18 to be kept w1th those who wrote and helped to enset the new law,.... If there is to be a hardbolled and tough 1nterpretation of the powers given under Fublle Law 167, and a wholesale attempt at cancellation of existing mining claims, we are going to have to go to bat and oppose your efforts most violently."

To date, the ITM has not learned of an ansear to this letter. When and if It comes to our attention, we will publish it, for it may have some bearing on the pending actions of the Forest Service on claims in Tongass Nationel Forest in SE Aleska. It should be remembered, too, that P I 167 applies to claims on all public domaln, not just forest lends. Other government agencles may get into the act later.

\section{STRAIEGIC MINERAIS BHIS}

As reported lest month, a large number of b111s have been Introduced in Congrees to extend the purchasing programs of strateglc minerals. They are senate b1Ils, and the senate policy or strategy appears to be to have b111s covering the many phases of the strategic minerals situation separately and collectively, and then have the Admialstration and the mining 1ndustry decide which they want and will approve. All minerals covered previously have been Included again plus a ncw one for antimony (very limited) and also a bill to create a floor price for mercury. The billa are sponsored by Senators from the States in which the particular minerals are of greatest iaportance. Congressional experts say that no separate bill could get sufficleat support, but that a blll covering all the minerals would bave a much better chance.

\section{GEOPHYSICAL IOCATIONS FROPOSED}

8. 3484 is a bill introduced by Senator Murray of Montana wh1ch would a) low claims to be staked as a result of geophysical, geochentcal, or geological work or anomalies in addition to the conventional discovery of mineral in place. Simflar bilis have been introduced regularly since 1947, but never with much support. Now, wth the enormous increase in geophysical prospecting caused mostly by the expansion of the uranlum industry, the bill might get oufficlent favorable attention to pess. It would permit the locat1on of large arcas for the types of prospecting Indicated and would also permit the validation of clatms without the time-honored "discovery" of minerel in place. At the same time it would not disturb the present mining laws, and the prospector would st1ll and up with the traditional unpatented claims. Anmuel assessment work would still be required. 


\section{MISCELIANEOUS}

Reminder: The assessment work year ends on Jwily firtt at noon.

The University of Alaska School of Mines at College has published a booklet entitled Elementary Geochemical Prospecting Methods. The methods explained have been developed by the USGS and the School of Nines. The booklet is avallable at the school for $\$ 1$.

Delegete Bartlett is requesting that a Small Business Administration office be located in Alaska. If successful, it probsbly still won't benefit Alasican miners. In the courbe of Its existence, SBA has so far approved only three mall loans to metal mining enterprises, and those were later cancelled for varlous reasons.

It has fust been announced that uranfun buying by the Government will be extended flve years beyond the 1962 explration date of the present program. We do not yet have the detalis on this.

\section{BARITE}

The largest use of barlte, and one that takes nearly three-fourths of the total output, is as a welghting agent in rotary well-drijling fluids. Such fluids serve several purposes - lubricating and cooling the bit, plastering the walls to prevent caving of the hole; carrylng the cuttings up the well to the surfece, and the main purpose: restraining abnormally high gas and oil pressures to their formation levels. A number of 11 rms make a large pert of thelr Ilvelihood from preparing arliling mad from barlte and selling it to oll-well drilling outfits. A large tonnage of berite is used in lithopone, whlch 18 a mixture of zinc sulfide and barium sulfate and 18 used as a white plgment, mostiy in paints. Barite 18 also used in glass making; as filler in many items such as ink, ollcloth, linoleum, mibber, etc., and as a raw materlal in the making of various barlum chemicals which are widely used in many industries. There is a trend toward the increased use of barlte as on aggregate to welght concrete eround pipelines in river crossings and owempy arees.

Barlte 18 naturally occurring barlum sulfate, and is the principal barlum mineral produced commercially. It is also called "barytes" or "heavy apar" in certain localities. Pure barite is white, and opeque to transparent. Impuritles cause a Hide varlation in color, commonly buff, Bray and white with irreguler reddish Iron stains. Less frequentIy found are shades of yellow, green, blue, brown, and black. The rock 18 brittle and breaks with an pneven fracture, although epecimens often appear to heve a cleavage due to seperation of layers of deposition. Hardness varies from 2.5 to 3.5. Specif1c gravity of pure barite 1s 4.5, and this will vary downward, depending on Impurities present. Barlte has a white streak and a pearly to vitreous, or sometimes stony; luster. It's classed as a nonmetallic.

Witherite is somewhet similar in appearance and welght to barite. It is a barlum carbonate. It $1 s$ mined in Great Britain and small quantitles are imported Into the U.S.

Small deposits of bartte are widegpread in Alaslea, but there is only one known deposit of comercial possibilities at the present time. This is a deposit on one of the Castle Irlands in Duncan Canal, Southeastern Alaska. It is estimated 
to contain 50,000 tone of $90 \%$ bartte above high tide. It 1s on patented ground and held by the Alaska Juneeu Gold llining Co. A number of interesting but mall occurrences of barlte and witherite are on northern Kulu Island. Because of the low unit price of berite, the only chance of a commercial barite mining venture in Alasks would be one in which a company with its own transportation fac1lities courd take over a deposit. In the case of the Castle Island deposit, the material could be loeded drectiy into a barge from the pit.

For drilling mud, the barlte mast have a speciflc grevity of at least 4.2, with some companies insiating on 4.3. The crude o1l well grade of $4.3 \mathrm{sp} . \mathrm{g}$. is quoted at $\$ 11.50$ per ton at present. A crude ore of minimum $94 \%$ barite and less than $1 \%$ iron 18 quoted at $\$ 16.00$ per ton. Canadian prices at the shipping point are $\$ 11$ per long ton for crude in bulk, and $\$ 6.50$ per short ton for ground ore in bage.

E. MND M.J. METAL MARKET PRICES

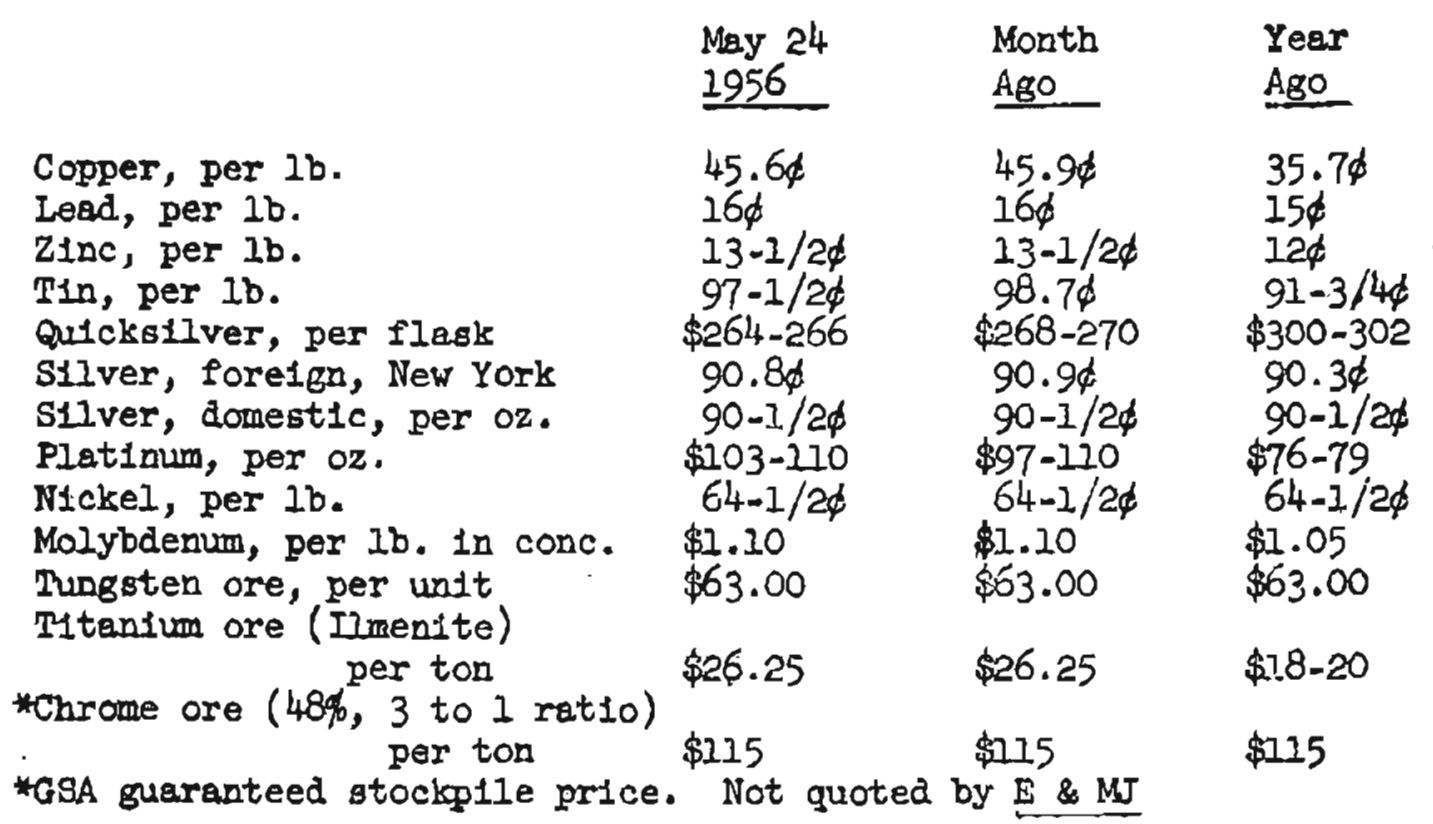

